\title{
THE STUDY OF TOXICOLOGICAL PROPERTIES OF "METROXAL" CREAM
}

\author{
L.M.Maloshtan, V.Ye.Yurchenko N.P.Polovko, I.O.Tymoshyna
}

\author{
National University of Pharmacy
}

Key words: dermatological diseases; toxicological research; creams

\begin{abstract}
The presence of Demodex folliculorum mites exacerbates the number of dermatological conditions, such as rosacea and perioral dermatitis, and complicates their treatment. Development and introduction of medicines with the complex action in practical medicine exhibiting anti-parasitic properties against Demodex folliculorum and possessing the antibacterial, anti-inflammatory, capillary-restorative, anti-edemic, antioxidant and anti-allergic effect are of great current interest. One of the stages of introduction of new medicines is to study toxicity, which allows to assess their safety. Acute toxicity, the skin-irritant effect of the cream containing metronidazole, salicylic acid, troxerutin and essential oil of lemon balm, as well as its anti-alterative activity have been experimentally investigated on the model of non-allergic contact subchronic dermatitis caused by turpentine. The results obtained show no toxicity and skin-irritant effect of the cream with a single topical application to rats in the doses of 500 and $15000 \mathrm{mg} / \mathrm{kg}$; it allows to refer it to Class VI of practically non-toxic substances $(L D>15000 \mathrm{mg} / \mathrm{kg}$ ) in accordance with the generally accepted classification of K.K.Sidorov. As a result of the study of the anti-alternative activity on the model of non-allergic contact subchronic dermatitis caused by turpentine it has been found that the cream under research reveals the anti-inflammatory action.
\end{abstract}

$\mathrm{D}$ emodicosis is an invasive dermatozoonosis caused by abnormal multiplication of mites of Demodex genus, which are opportunistic parasites because they can parasite on the human skin for a long time in a small amount, mainly on the face, and do not reveal any symptoms and pathological changes of the skin $[10,11]$. However, under favourable conditions, in which the parasites propagate rapidly and increase their activity, there are clinical signs of demodicosis in the form of the skin inflammation [5, $10,11]$. The presence of Demodex folliculorum mites exacerbates the number of dermatological conditions, first of all, rosacea and perioral dermatitis [5]. Besides some usual manifestations, the presence of skin demodicosis can lead to micropapulae and follicular pustules that contain mites [5].

The treatment of demodicosis includes both systemic and topical therapy, in which the acaricidal therapy takes the main place [4]. The use of metronidazole, birch tar, benzyl benzoate is rather effective, besides the treatment regimen includes the drugs that contain salicylic acid and resorcinol $[5,6,9]$.
The composition of a cream that contains metronidazole, salicylic acid and troxerutin under conditional name "Metroxal" has been developed. Metronidazole has long proven itself to be an effective remedy in treating rosacea and demodicosis as it exhibits the bacteriostatic effect, as well as the antiparasitic properties in relation to Demodex folliculorum $[4,6]$. Metronidazole intensifies the protective and regenerative functions of the skin and mucous membranes and has a pronounced anti-edemic effect $[6,8]$. Acting on the autonomic nervous system metronidazole also stimulates its adrenergic structures, reduces congestions, erythema and even teleangiectasian changes $[6,8]$. Salicylic acid exhibits antibacterial and anti-inflammatory, keratolytic or keratoplastic (5\%) properties, troxerutin provides venotonic, capillary-restorative, angioprotective, anti-edemic, antioxidant and antiinflammatory effects [6].

According to the guidelines when studying a new medicine its toxicity must be researched to assess the degree of the drug safety. The more efficient and safer a medicine is, the greater is its po-

L.M.Maloshtan - Doctor of Biology, professor, head of the Physiology Department, head of the Morphofunctional Research laboratory of the National University of Pharmacy (Kharkiv)

tential use in medical practice. Taking it into consideration the purpose of our work was to study the acute toxicity and to evaluate the possible effect of the local irritating action of the cream developed.

\section{Materials and Methods}

Acute toxicity was studied by G.V.Pastushenko method on nonlinear outbread mature white rats of both sexes weighing 180-230 g with a single cutaneous application using two dose levels. Assessment of toxicity was performed by the standard classification of Sidorov K.K.

The study of anti-alternative properties of "Metroxal" cream was performed on the model of nonallergic contact subchronic dermatitis caused by turpentine [2]. The study was conducted on white female rats weighing $180-230 \mathrm{~g}$. The rats' skin was previously depilated in accordance with the guidelines. Animals were divided into 2 groups of 5 rats in each. The groups were divided in the following way: 1 - untreated control, 2 - animals with the cream applied. After modelling the disease within 10 days once a day the rats were applied with a thin layer of the cream under research.

The condition of the skin covers of animals was evaluated in points: 0 points - no visible dama- 
The study of acute toxicity of the cream

\begin{tabular}{|c|c|c|c|c|}
\hline \multirow{2}{*}{$\begin{array}{c}\text { The group } \\
\text { of animals }\end{array}$} & \multirow{2}{*}{ Dose, $\mathrm{mg} / \mathrm{kg}$} & \multicolumn{2}{|c|}{ Number of animals in groups } & \multirow{2}{*}{ The visual effect } \\
\cline { 3 - 4 } & & dead & surviving animals & \\
\hline Cream & 5000 & 0 & 5 & The skin without change \\
\hline Cream & 15000 & 0 & 5 & The skin without change \\
\hline
\end{tabular}

Table 2

\section{The results of the study of the anti-alterative activity of the cream on the model of non-allergic contact subchronical dermatitis $(n=5)$ on the tenth day}

\begin{tabular}{|l|c|c|c|c|}
\hline \multirow{2}{*}{\begin{tabular}{c}
\multirow{2}{*}{$\begin{array}{c}\text { Conditions } \\
\text { of the study }\end{array}$} \\
\cline { 2 - 5 }
\end{tabular}} & \multicolumn{2}{|c|}{ The condition of the skin of animals, points } & \multirow{2}{*}{$\begin{array}{c}\text { Change of the skin } \\
\text { fold thickness, mm }\end{array}$} & $\begin{array}{c}\text { Anti-alterative } \\
\text { activity, } \%\end{array}$ \\
\hline Untreated control & $2.40 \pm 0.25$ & $0.80 \pm 0.20$ & $0.460 \pm 0.070$ & - \\
\hline "Metroxal" cream & $2.40 \pm 0.25$ & $0.40 \pm 0.25$ & $0.242 \pm 0.080$ & 47.39 \\
\hline
\end{tabular}

ge, 1 point - congestion with a small scaling, 2 points - moderately severe congestion, and 3 points cutting congestion, a peel with ulcers. To assess the severity of inflammation and the action of medicines in animals we studied the skinfold thickness. All parameters were determined before the beginning of the experiment, at the peak of the disease modelling and on the tenth-day of the topical treatment of dermatitis.

The anti-alternative activity was determined by the degree of inhibition of the skin expression state in animals with the cream applied to the animal of the control pathology, and it was expressed in percentage [2].

All results were processed using a special computer programme Statistica 5,0 for Windows. Statistical analysis of the results of the research was carried out by coefficients of Student's (t) and Wilcoxon-Mann-Whitney (w) $[1,3,7]$.

\section{Results and Discussion}

The study of acute toxicity of the cream with cutaneous application to rats.

Taking into account the fact that the cream is used for external use we investigated the pos- sible toxic effects after a single cutaneous application. Acute toxicity was studied in rats, the cream was applied on the clipped skin.

Having observed the animals for two weeks the symptoms of intoxication were not found. The results are presented in Table 1.

The skin covers and reflex excitability in all animals after a single application of the cream during the observation period were unchanged.

The results of the study indicate the absence of toxicity and the skin-irritant action of the cream after a single cutaneous application to the rats in two doses studied.

Thus, based on the research in accordance with the generally accepted classification by K.K.Sydorov the cream belongs to the class VI of practically non-toxic substances (LD> $15.000 \mathrm{mg} / \mathrm{kg}$ ).

The study of anti-alternative properties of the cream [2].

The results of the study of the anti-alternative properties of the cream on the model of non-allergic contact subchronic dermatitis caused by turpentine [2], are given in Table 2.

These data have shown the influence of the cream containing salicylic acid, metronidazole and troxerutin on the alternative phase of inflammation as it is evidenced by the significant improvement of the skin in points resulting in reduction of congestion to 0.4 points compared to controls (0.8 points). Decrease of contact dermatitis caused by turpentine according to the results of changes of the skin folds under the influence of the cream was 47.39\%.

Thus, these results have shown the anti-inflammatory action of the cream on the model of non-allergic contact dermatitis in rats.

\section{CONCLUSIONS}

The results obtained experimentally show no toxicity and skin-irritant effect of the cream with a single topical application to rats in the doses of 500 and $15000 \mathrm{mg} / \mathrm{kg}$; it allows to refer "Metroxal" to Class VI of practically non-toxic substances (LD > $15000 \mathrm{mg} / \mathrm{kg}$ ) in accordance with the generally accepted classification of K.K.Sidorov

As a result of the study of the anti-alternative activity on the model of non-allergic contact subchronic dermatitis caused by turpentine it has been found that the cream under research reveals the anti-inflammatory action.

\section{REFERENCES}

1. Гляни С. Медико-биологическая статистика / Пер. с англ. - М.: Практика, 1998. - 459 с. 
2. Доклінічні дослідження лікарських засобів: Метод. рекоменд. / Под ред. О.В. Стефанова. - К.: Авіценна, 2001. - 528 с.

3. Иванов Ю.И., Погорелюк Р.Н. Статистическая обработка результатов медико-биологических исследований на микрокалькуляторах по программам. - М.: Медицина, 1990. - 224 с.

4. Коган Б.Г., Степаненко В.І. // Укр. журн. дерматол., венерол., косметол. - 2006. - №1. - С. 14-28.

5. Коган Б.Г., Горголь В.Т., Степаненко В.І. та ін. // Укр. журн. дерматол., венерол., косметол. 2002. - №4. - C. 50-54.

6. Компендиум 2008 - Лекарственные препараты: Справ. / Под ред. В.Н.Коваленко, А.П.Викторова. - К.: Морион, 2008. - 2120 с.

7. Лапач С.М., Чубенко А.В., Бабіч П.М. Статистичні методи в медико-біологічних дослідженнях із застосуванням Exсеl. - К.: Моріон, 2001. - 408 с.

8. Рябченко И.Н. // Укр. журн. дерматол., венерол., косметол. - 2007. - №3. - С. 93-95.

9. Dahl M.V., Jarratt M., Kaplan D. // J. Am. Acad. Dermatol. - 2001. - Vol. 45. - P. 723-730.

10. Desch C.E., Nutting W.B. // Acarol. - 2007. - Vol. 19, №3. - P. 422-462.

11. Nultinff W.B., Geer A.C. // Br. J. Dermatol. - 2006. - Vol. 9, №4. - P. 34-38.

\title{
ВИВЧЕННЯ ТОКСИКОЛОГІЧНИХ ВЛАСТИВОСТЕЙ КРЕМУ «МЕТРОКСАЛ»
}

Л.М.Малоштан, В.є.Юрченко, Н.П.Половко, І.О.Тимошина

Національний фармацевтичний університет

Ключові слова: дерматологічні захворювання; токсикологічні дослідження; креми

\begin{abstract}
Наявність кліща Demodex folliculoruт ускладнює перебіг низки дерматологічних захворювань, таких як розацеа і періоральний дерматит та утруднює їх терапію. Актуальним є розробка та впровадження у практичну медицину лікарських препаратів комплексної дії, які проявляють антипаразитарні властивості щодо Dетодех folliculorum, володіють антибактеріальною, протизапальною, капілярозміцнювальною, протинабряковою, антиоксидантною та протиалергічною дією. Одним із етапів впровадження нових лікарських препаратів $\epsilon$ дослідження токсичності, що дозволяє оцінити ступінь їх безпеки. Експериментально досліджено гостру токсичність, шкірноподразнювальну дію крему, який містить метронідазол, саліцилову кислоту та троксерутин, а також його антиальтеративну активність на моделі неалергічного контактного субхронічного дерматиту, викликаного скипидаром. Отримані результати свідчать про відсутність токсичного впливу і шкірноподразнювальної дії крему при одноразовому нашкірному нанесенні шурам у дозах 5000 і 150000 мг/кг, що дає змогу віднести його відповідно до загальноприйнятої класифікації К.К.Сидорова до VI класу практично нетоксичних речовин (ЛД > 15000 мг/кг). У результаті вивчення антиальтеративної активності на моделі неалергічного контактного субхронічного дерматиту, викликаного скипидаром, встановлено, що досліджуваний крем проявляє протизапальну (антиальтеративну) дію.
\end{abstract}

\section{ИЗУЧЕНИЕ ТОКСИКОЛОГИЧЕСКИХ СВОЙСТВ КРЕМА «МЕТРОКСАЛ» \\ Л.Н.Малоштан, В.Е.Юрченко, Н.П.Половко, И.А.Тимошина \\ Национальный фармацевтический университет}

Ключевые слова: дерматологические заболевания; токсикологические исследования; кремы

Наличие клеща Demodex folliculorum усугубляет течение ряда дерматологических заболеваний, таких как розацеа, периоральный дерматит и усложняет их терапию. Актуальным является разработка и внедрение в практическую медицину лекарственных препаратов комплексного действия, которые проявляют антипаразитарные свойства по отношению к Deтоdex folliculorum, а также обладают антибактериальным, противовоспалительным, капилляроукрепляющим, противоотечным, антиоксидантным и противоаллергическим действием. Одним из этапов внедрения новых лекарственных препаратов является исследование токсичности, позволяющее оценить степень их безопасности. Экспериментально исследована острая токсичность, кожнораздражающее действие крема, содержащего метронидазол, салициловую кислоту и троксерутин, а также его антиальтеративную активность на модели неаллергического контактного субхронического дерматита, вызванного скипидаром. Полученные результаты свидетельствуют об отсутствии токсического воздействия и кожнораздражающего эффекта крема при однократном наружном нанесении крысам в дозах 5000 и 150000 мг/кг, что позволяет отнести его в соответствии с общепринятой классификацией К.К.Сидорова к VI классу практически нетоксичных веществ (ЛД > 15000 мг/кг). В результате изучения антиальтеративной активности на модели неаллергического дерматита, вызванного скипидаром, установлено, что опытный крем проявляет противовоспалительное (антиальтеративное) действие.

12, Melnikov str., Kharkiv, 61002, Ukraine.

Tel. (57) 706-30-73. E-mail: physio@ukrfa.kharkov.ua.

National University of Pharmacy 